\title{
UPACARA MEMBATUR: SARANA PENDIDIKAN DALAM MEMBENTUK KARAKTER PADA MASYARAKAT DAYAK HALONG
}

\author{
MEMBATUR CEREMONY: \\ EDUCATIONAL FACILITIES IN FORMING CHARACTER IN DAYAK \\ HALONG COMMUNITY
}

\author{
Sisva Maryadi \\ Balai Pelestarian Nilai Budaya Kalimantan Barat \\ Jalan Sutoyo Pontianak \\ HP:081374389611. E-mail:s_yadi11@yahoo.co.id
}

\begin{abstract}
Abstrak
Kajian ini bertujuan untuk mengungkapkan upacara tradisional pada masyarakat Dayak Halong yang masih dilaksanakan sampai saat ini. Penelitian ini dilakukan di Kecamatan Halong, Kabupaten Balangan, Provinsi Kalimantan Selatan. Dalam tulisan ini dideskripsikan bagaimana jalannya upacara, bahan yang dipakai untuk upacara dan beberapa manfaat upacara dalam pembentukan karakter pada masyarakat Dayak Halong. Hal penting dalam pelaksanaan upacara ini adalah kepatuhan masyarakat pendukung kebudayaan tersebut maupun masyarakat luar yang tinggal di sekitar komunitas yang bersangkutan dalam mematuhi segala larangan dan pantangan yang diakibatkan dalam pelaksanaan upacara tersebut. Upacara Membatur ini adalah upacara yang dilaksanakan oleh masyarakat untuk membuatkan rumah bagi arwah leluhur yang telah meninggal. Penelitian yang dilakukan ini bersifat deskriptif dengan pendekatan kualitatif. Pengumpulan data primer dilakukan dengan teknik pengamatan dan wawancara mendalam. Informan dipilih berdasarkan metode snowball sampling sesuai dengan tujuan penelitian.
\end{abstract}

Kata kunci: Membatur, Upacara Tradisional, Dayak Halong, Karakter

\begin{abstract}
This study aims to reveal traditional ceremonies in the Halong Dayak community that are still being carried out to date. This research was conducted in Halong District, Balangan Regency, South Kalimantan Province. This paper described how the ceremony, the materials used for the ceremony and some ceremonial benefits in the formation of characters in the Dayak Halong community. The important thing in the implementation of this ceremony is the adherence of the supporters of the culture and the outside community who live around the community concerned in compliance with all the restrictions and abstinence that resulted in the implementation of the ceremony. This Membatur Ceremony is a ceremony performed by the community to make a home for the dead ancestral spirits. This research is descriptive with qualitative approach. Primary data collection was done by observation techniques and in-depth interviews. Informants were selected based on the snowball sampling method in accordance with the research objectives.
\end{abstract}

Key words: Membatur, Traditional Ceremony, Halong Dayak, character 


\section{PENDAHULUAN}

Negara Indonesia merupakan sebuah negara dengan kekayaan tradisi yang beraneka ragam di dalamnya. Adat dan tradisi dari masing-masing suku bangsa tersebut satu sama lainnya berbeda dan mempunyai ciri khas tersendiri. Kebudayaan-kebudayaan dari berbagai suku bangsa tersebut merupakan bagian dari kebudayaan nasional dan setiap suku bangsa tersebut terikat pada adat dan tradisi yang berlaku pada lingkungan etnisnya masing-masing.

Kebudayaan dari masing-masing daerah ini banyak memiliki aspek pendidikan dalam kehidupan sehari-hari. Pendidikan yang banyak kita temui tersebut adalah pelajaran tentang kehidupan masyarakat, pelajaran tentang alam dan pelajaran tentang prilaku sehari-hari, terutama dalam pembentukan karakter diri pribadi. Pembentukan karakter ini terdapat dalam berbagai aktifitas sehari-hari dalam masyarakat tradisional. Upacara yang biasa dilaksanakan oleh masyarakat tradisional merupakan salah satu aspek pendidikan dalam pembentukan karakter yang baik dalam masyarakat tersebut.

Dalam tulisannya, Ajisman, dkk, (1998) menyatakan bahwa Upacara tradisional merupakan ritus kepercayaan yang padat dan penuh dengan nilai-nilai dan norma-norma kehidupan masyarakat pendukungnya. Upacara tradisional bertujuan untuk menghormati, mensyukuri dan memuja kepada Tuhan melalui makhluk halus dan leluhurnya. Dalam upacara tradisional ini terjadi hubungan antara otoritas leluhur atau Tuhannya dengan pemujanya dimana mereka meyakini para leluhur atau Tuhan tersebut dapat memberikan sesuatu yang bermakna bagi pemujanya. Para pemujanya percaya bahwa manusia memiliki keterbatasan untuk mencapai suatu tujuan, maka mereka meyakini bahwa dengan bantuan leluhur semua itu dapat di capai.

Peranan upacara berguna untuk mempersatukan sistem paralel dan yang berbeda tingkat hirarkinya dengan menempatkan pada hubungan normatif dan reflektif antara yang satu dengan yang lainnya dalam suatu cara yang dihubungkan dengan asal mula simboliknya dan asal mula pernyataannya. Secara keseluruhan, upacara mempunyai kedudukan sebagai perantara simbolik atau dikatakan perantara metafor dalam kaitannya dengan kebudayaan. Upacara mampu menterjemahkan tingkat-tingkat tertentu yang ada dalam kenyataan sosial menjadi tingkat yang lebih tinggi, sehingga membuat manusia menjadi sadar lewat panca indera serta perasaannya.

Salah satu upacara pada masyarakat Dayak Halong yang dapat membentuk karakter bagi masyarakatnya adalah upacara membatur. Upacara membatur adalah upacara pembuatan rumah bagi arwah leluhur yang dilaksanakan oleh masyarakat Dayak Halong. Upacara ini tidak setiap saat bisa dilaksanakan, karena membutuhkan perencanaan, biaya dan waktu yang tepat. Dalam pelaksanaan upacara ini ada beberapa pelajaran yang bisa membentuk karakter bagi masyarakat Dayak Halong. Karakter ini tidak terbentuk begitu saja, tetapi melalui proses panjang dan telah dimulai sejak dini.

Berdasarkan rumusan permasalahan di atas maka tujuan penulisan ini adalah mengetahui karakter apa saja yang bisa dibentuk dalam pelaksanaan upacara membatur ini. Didalam tulisan ini juga akan dibahas mengenai tata cara pelaksanaan upacara membatur yang masih bertahan di masyarakat Dayak Halong. 
Pelaksanaan upacara membatur telah menjadi tradisi bagi masyarakat Dayak Halong dan sudah menjadi bagian dari kebudayaan mereka. Tradisi-tradisi yang turun-temurun inilah yang nantinya lahir menjadi sebuah budaya yang menjadi identitas suatu masyarakat tertentu. Kebudayaan menurut Taylor (Liliweri, 2014) adalah kumpulan yang kompleks dari pengetahuan, kepercayaan, seni, hukum, moral, adat istiadat dan setiap kemampuan lain atau kebiasaan yang diperoleh oleh manusia sebagai anggota masyarakat. Sementara Geertz (Yusuf, 1983; Maryadi, 2010) berpandangan kebudayaan adalah pola dari makna yang terjalin secara menyeluruh dalam simbol-simbol yang ditransmisikan secara historis adalah suatu sistem tentang konsepsi-konsepsi yang diwariskan dalam bentuk simbolik dimana manusia berkomunikasi dan mengembangkan pengetahuan dan sikap mereka terhadap kehidupan.

Lebih lanjut dijelaskan bahwa simbol-simbol adalah benang penghubung antara pemikiran manusia dengan kenyataan yang ada diluar dirinya. Dengan demikian simbol-simbol itu pada hakekatnya terdiri atas dua macam yakni:

1. berasal dari dalam yang terwujud melalui konsepsi-konsepsi dan struktur sosial

2. berasal dari luar yang berwujud sebagai kenyataan-kenyataan sosial.

Dalam hubungan ini simbol-simbol tersebut menjadi dasar bagi perwujudan modelmodel dari sistem konsepsi dalam suatu cara dengan bagaiman mewujudkan bentuk sistem sosial. Sistem kebudayaan dengan demikian dilihat sebagai persamaan struktur dinamik yaitu dalam bentuk-bentuk simbolik. Menurut Durkheim (Jenks, 2013) simbol-simbol yang ditampilkan tersebut menjadi sumber identitas dan pengakuan terhadap kelompok, menjadi sesuatu yang mereka sembah, puja dan hormati.

Koentjaraningrat (1987) menyebutkan bahwa sistem ritus dan upacara biasannya berlangsung berulang-ulang, baik setiap hari, setiap musim, atau kadang-kadang saja. Tergantung dari isi acaranya, suatu ritus atau upacara religi biasanya terdiri dari suatu kombinasi yang merangkainya satu-dua atau beberapa tindakan seperti: berdoa, bersujud, bersaji, berkorban, makan bersama, menari dan menyanyi, berpuasa, bertapa dan bersamadi. Dalam ritus biasanya dipergunakan bermacam-macam sarana dan peralatan serta para pelakunya sering kali harus mengenakan pakaian yang juga dianggap mempunyai sifat suci.

Menurut Guntara, dkk, (2016) dalam konteks kebudayaan, pendidikan memainkan peranan dalam agen pengajaran nilai-nilai budaya. Pendidikan yang berlangsung adalah proses pembentukan kualitas manusia sesuai dengan kodrat budaya yang dimiliki. Nilai-nilai kebudayaan diharapkan dapat membentuk generasi yang berkarakter. Nilai-nilai budaya tersebut (Wardani, 2015) telah tertanam dalam masyarakat yang mengakar pada kebiasaan, kepercayaan, simbol-simbol dengan karakteristik tertentu yang dapat dibedakan satu dan lainnya sebagai acuan perilaku dalam masyarakat.

Seperti halnya dalam setiap pelaksanaan upacara-upacara tradisional, dalam setiap tahapan upacara, kita selalu dapat melihat ada proses dalam membentuk karakter. Dalam Kehidupan sehari-hari, seringkali kita menyamakan antara karakter dengan watak, sifat ataupun kepribadian. Padahal, jika di uraikan lebih lanjut arti dari kata karakter dengan watak tidaklah 
sama. Karakter merupakan akumulasi dari sifat, watak dan juga kepribadian seseorang. Karakter menurut Kamus Umum Bahasa Indonesia ${ }^{1}$ adalah tabiat; sifat-sifat kejiwaan, akhlak atau budi pekerti yang membedakan seseorang dengan yang lain. Menurut Adibatin (2016) Karakter hakikatnya adalah watak, tabiat, akhlak, atau kepribadian seseorang yang terbentuk dari hasil internalisasi berbagai kebajikan (virtues) yang diyakini dan digunakan sebagai landasan untuk cara pandang, berpikir, bersikap, dan bertindak. Pendapat lain dikemukakan oleh Muchlas Samani dan Hariyanto (Nugraha, 2012) menyatakan bahwa karakter dapat dimaknai sebagai nilai dasar yang membangun pribadi seseorang, terbentuk baik karena pengaruh hereditas maupun pengaruh lingkungan, yang membedakannya dengan orang lain, serta diwujudkan dalam sikap dan perilakunya dalam kehidupan sehari-hari

Karakter yang dimiliki oleh seseorang itu pada dasarnya di dapat melalui proses pembelajaran yang cukup panjang karena karakter seseorang itu di bentuk dari pembelajaran di rumah, sekolah dan lingkungan di sekitar tempat tinggal. Begitu juga halnya dengan upacara membatur ini. sepanjang proses pelaksanaan upacara, semua aktifitas yang dilakukan penuh dengan pendidikan yang dapat membentuk karakter seseorang.

\section{METODE PENELITIAN}

Penelitian tentang Upacara Membatur ini dilakukan di Kecamatan Halong Kabupaten Balangan Kalimantan Selatan. Sifat penelitian ini adalah penelitian deskriptif yang bertujuan untuk menggambarkan Upacara Membatur. Penelitian ini menggunakan pendekatan kualitatif yang menjadikan informan atau keterangan yang diberikan oleh para informan dalam penelitian ini sebagai tolok ukur dalam pemaparan dan analisi data penelitian yang di dapat. Dalam menerapkan pendekatan kualitatif tersebut, teknik pengumpulan data dilapangan dilakukan dengan observasi yang mengamati dan melihat kondisi di sekitar lokasi informan tinggal untuk memperoleh data mengenai kondisi fisik daerah penelitian, keadaan penduduk, keadaan sosial, ekonomi dan pendidikan.

Teknik lainnya adalah dengan wawancara mendalam dengan pertanyaan-pertanyaannya berbentuk pertanyaan terbuka. Wawancara dengan informan dilakukan dengan menggunakan pedoman wawancara yang telah disusun dan berisikan pokok-pokok permasalahan yang akan dikumpulkan yaitu tentang upacara, manfaat dan peran upacara tersebut dalam pendidikan di masyarakat. Wawancara ini ditujukan kepada informan atau tokoh-tokoh masyarakat yang mengetahui tentang upacara seperti balian, tokoh adat, pemerintah desa dan generasi muda Halong.

Pemilihan informan penelitian dilakukan dengan metode snowball yang mempertimbangkan rekomendasi dari informan awal dan informan lain yang telah diwawancarai. Selain menjadikan informasi yang bersumber dari pengamatan dan wawancara sebagai data primer, peneliti juga melakukan studi literatur dengan menggunakan sumber-sumber bacaan berupa buku, makalah yang diterbitkan di jurnal ilmiah, laporan penelitian yang dipublikasi,

\footnotetext{
${ }^{1}$ (http://kbbi.web.id/karakter)
} 
skripsi dan lain sebagainya. Tahap akhir dari semua itu adalah analisis data. Dalam tahap ini peneliti melakukan analisa mengenai data-data yang berhasil dikumpulkan dari kegiatan observasi dan wawancara untuk disusun dan diklarifikasi agar lebih mudah penyusunannya sesuai dengan ruang lingkup permasalahan.

\section{PEMBAHASAN}

\section{Sekilas Tentang Dayak Halong}

Orang Dayak di anggap sebagai penduduk asli pulau Kalimantan. Istilah Dayak adalah suatu sebutan umum untuk orang-orang atau kelompok-kelompok etnis yang sebagian besar non Islam dan hidup sepanjang sungai-sungai di pulau Kalimantan. Kata Dayak diartikan berbagai macam oleh peneliti sosial. Menurut J.A. van Hohendroff (Syamsudin, 2001) Dayak diartikan sebagai orang-orang pegunungan yang liar. Sementara menurut H. Scharer, istilah Dayak itu berasal dari Bahasa Melayu yang artinya penduduk asli: orang-orang melayu pantai menggunakan istilah backwoodsman ${ }^{2}$.

Masyarakat Dayak Halong bermukim di desa Kapul, kecamatan Halong, kabupaten Balangan, provinsi Kalimantan Selatan. Desa Kapul tidak hanya dihuni oleh masyarakat Dayak Halong, tetapi juga dihuni oleh berbagai suku bangsa seperti Jawa, Banjar dan Bugis. Sejak tahun 1970-an, masyarakat Dayak Halong menganut agama Budha. Sebelumnya mereka juga menganut agama Kristen, Hindu dan Islam yang dibawa ke daerah ini oleh para penyebar agama dari luar. Di dalam perkembangannya kini di kalangan masyarakat Dayak Halong telah sering terjadi perkawinan antaragama dan antaretnis.

Selain menjalankan ajaran agamanya, masyarakat Dayak Halong juga melaksanakan upacara-upacara tradisional yang berkaitan dengan kepercayaannya. Upacara tradisional/upacara adat pada umumnya diselenggarakan sebagai upaya untuk memperoleh ketenteraman, kebahagiaan dan kesejahteraan bagi seluruh warga masyarakatnya. Sementara Sastrowardoyo (1985) menyatakan bahwa upacara adat ini biasanya diikuti dengan pengorbanan-pengorbanan dan persembahan-persembahan kepada kekuatan yang dipandangnya menguasai alam (makrokosmos dan mikro-kosmos) untuk mendapatkan imbalan yang berlipat ganda bagi ketentraman, kebahagiaan dan kesejahteraan bersama.

Berdasarkan cerita turun temurun, masyarakat Dayak Halong merupakan salah satu bagian dari kerajaan Banjar yang di pimpin oleh Patih Lambung Mangkurat yang terkenal dengan Negara Dwipa. Pada masa dulu orang-orang Banjar ini adalah orang yang menganut kepercayaan Kaharingan, termasuk semua raja yang memerintah sampai pada masa pemerintahan Pangeran Suryansah. Pada masa itu terjadi perebutan tahta antara Pangeran Suryansah dengan pamannya. Untuk memenangi perebutan tersebut, Pangeran Suryansah meminta bantuan pada Kerajaan Demak dengan perjanjian kalau menang maka mereka harus masuk ke dalam agama Islam. Setelah Pangeran Suryansah menang perebutan kekuasaan dengan pamannya Pangeran

\footnotetext{
${ }^{2}$ Panggilan ini di pakai oleh orang-orang Melayu pesisir terhadap penduduk asli (orang dayak) dari Kalimantan. Penduduk melayu ini biasanya adalah pendatang yang datang dari luar pulau kalimantan.
} 
Mangkubumi, untuk memenuhi perjanjiannya dengan Kerajaan Demak, Pangeran lalu memberikan penawaran kepada para punggawa raja dan masyarakat, bagi yang tidak mau masuk Islam dipersilahkan untuk memisahkan diri. Sementara bagi yang mau masuk Islam maka mereka ikut dengan Pangeran Suryansah dan tinggal di pusat kota. Para punggawa dan masyarakat yang tidak masuk Islam lalu memisahkan diri pergi ke daerah pegunungan dengan mengikuti Pangeran Panji Kusuma. Mereka ini memilih berdiam di sepanjang Pegunungan Meratus dan masyarakat mengenal mereka sebagai orang Dayak. Pada masa dulunya para pengikut Pangeran Panji Kusuma (orang Dayak) ini bermukim atau berdiam secara menyebar dan tidak berkelompok di sepanjang pegunungan meratus. Akibat perkembangan zaman, maka muncullah desakan dan keinginan dari masyarakat Dayak (pengikut Pangeran Panji Kusuma) untuk hidup berkelompok, sehingga timbullah suatu perkembangan. Mulainya mereka hidup berkelompok sekitar tahun 80-an.

Kelompok-kelompok kecil itu lalu memberikan nama kelompok mereka dengan nama sungai yang mengalir di daerah sekitar mereka tinggal. Kelompok-kelompok kecil itu antara lain Dayak Rumping, Dayak Balanghan, Dayak Pitap dan lain sebagainya. Menurut informan, dulunya di sekitar Desa Kapul bermukim dua sub etnis Dayak yaitu Dayak Balanghan dan Dayak Halong yang hidup di dua aliran sungai yaitu Sungai Balanghan ${ }^{3}$ dan sungai Halong. Dayak Balanghan bermukim di bagian atas Desa Kapul sekarang yaitu Desa Tabuan dan Desa Uren. Sementara Dayak Halong bermukim dari atas deretan Sungai Halong. Kemudian kedua sub etnis tersebut sama-sama turun menyisir sungai dan menyatu di Desa Kapul. Pada awalnya sub etnis ini dinamakan dengan nama Dayak Balanghan Halong yang merupakan gabungan dari kata Balanghan dan Halong. Dalam pergaulan sehari-hari terjadilah kawin campur diantara mereka dan secara perlahan-lahan nama balanghan dihilangkan dan sekarang dikenal dengan nama halong. Selain itu nama Balanghan tersebut di ambil sebagai nama kabupaten baru yang berpusat di Paringin. Di ambilnya nama Balangan tersebut disebabkan nama tersebut merupakan nama sungai dengan alur yang terbesar di daerah tersebut. Nama balanghan tetap mereka pakai ketika mereka keluar dari kabupaten Balangan seperti acara-acara di tingkat provinsi dan di tingkat nasional. Sementara untuk tingkat kabupaten mereka tetap memakai nama Dayak Halong.

\section{Upacara Membatur}

Dalam tulisannya, Setyawan (2009) menyatakan bahwa sistem kepercayaan atau agama bagi masyarakat Dayak hampir tidak dapat dipisahkan dengan nilai-nilai budaya dan kehidupan sosial ekonomi mereka sehari-hari. Hal ini berlaku pula pada nilai-nilai budaya dan etnisitas dalam masyarakat Dayak. Ini berarti bahwa kepribadian, tingkah laku, sikap dan kegiatan sosial ekonomi masyarakat Dayak sehari-hari di dukung oleh dan dihubungkan tidak saja dengan sistem kepercayaan atau ajaran agama dan adat istiadat atau hukum adat, tetapi juga dengan nilai-nilai budaya dan etnisitas misalnya saja nazar atau niatan (janji) terhadap sesuatu hal. Dengan demikian respon mereka terhadap stimulus atau tekanan dari luar sering didasarkan

\footnotetext{
${ }^{3}$ Pemakaian kata Balanghan ini sudah jarang dipakai oleh masyarakat dan karena ingin kemudahan dalam pelafalan, maka kata balanghan sekarang lebih dikenal dengan kata Balangan
} 
kompleksitas unsur-unsur di atas. Masyarakat etnis Dayak memiliki suatu sistem kepercayaan yang kompleks dan sangat berkembang. Kompleksitas sistem kepercayaan tersebut berdasarkan pada tradisi dalam masyarakat Dayak mengandung dua hal prinsip yaitu; 1). Unsur kepercayaan pada nenek moyang yang menekankan pada pemujaan kepada-Nya, dan 2). Kepercayaan terhadap Tuhan yang satu dengan kekuasaan tertinggi dari kehidupan manusia.

Lebih lanjut dalam tulisan itu disebutkan bahwa dalam sistem kebudayaan Dayak dapat ditemui kegiatan-kegiatan seremonial yang berkaitan pada dua hal yaitu; 1). kegiatan pertanian, 2). upacara kematian. Masyarakat Dayak di Kecamatan Halong secara otomatis terikat dengan aturan adat. sejak seseorang itu dilahirkan sampai dengan mati. mulai dari lahir ada adat melahirkan, berladang dan berusaha berkebun lainnya ada adat, perkawinan juga ada adatnya sampai dengan kematian bahkan setelah di kubur pun ada adatnya seperti membatur. dalam konsep kepercayaan kaharingan segala upacara adat selalu berfokus pada roh, karena rasa takut akan dihancurkan atau di ganggu dan karena manusia perlu pertolongan dalam menghadapi berbagai kehidupan maka seolah-olah dalam semua kegiatan masyarakat pendukung kaharingan ditujukan pada upacara pemujaan roh.

Membatur adalah upacara yang dilaksanakan oleh masyarakat Dayak Halong yang bertujuan untuk membuatkan rumah bagi orang yang telah meninggal dunia. Upacara ini dipahami sebagai salah satu bukti wujud dan rasa terima kasih dari orang-orang yang masih hidup pada almarhum atas pengorbanannya semasa masih hidup. upacara membatur ini sudah dilakukan sejak dahulu dan merupakan salah satu kebiasaan dari nenek moyang masyarakat Dayak Halong. pada hakikatnya membatur adalah upacara mengantar roh yang diikuti dengan pembuatan batur di atas kubur si mati oleh ahli waris.

Pembuatan batur menandakan bahwa upacara pengantaran roh ke alam keabadian telah dilakukan. dengan upacara tersebut maka para ahli waris telah terbebas dari kewajibannya. Bagi ahli waris yang meninggal upacara membatur ini juga berfungsi untuk memanggil roh si mati agar menjadi dewa pelindung keluarga. Dalam posisi ini roh tersebut dapat memberi petunjuk dan bantuan jika keluarga yang ditinggalkan sedang mengalami kesusahan. Lebih jauh Setyawan (2009) mengatakan jika roh yang diupacarai adalah laki-laki maka roh tersebut akan menjadi dewa keselamatan, namun jika roh tersebut adalah perempuan maka ia akan menjadi dewa pemberi rezeki.

Acara membatur dapat dilaksanakan kapan saja tergantung kemampuan ahli warisnya. Kalau ahli warisnya mampu untuk melaksanakan membatur pada saat seseorang meninggal dunia, maka upacara tersebut dapat dilaksanakan saat itu juga, tidak perlu menunggu sampai bertahun-tahun. Ada keyakinan dalam masyarakat bahwa sebelum yang meninggal itu di batur, roh yang meninggal itu belum sampai ke tujuannya (surga) dan masih mengembara kemanamana. Oleh karena itu semakin cepat pelaksanaan membatur, berarti arwah tersebut makin cepat pula sampai ke tujuan. Waktu pelaksanaan dan besarnya upacara membatur tidak mengikat, kapan saja dan jumlah hewan kurban yang di potong tidak harus sama untuk tiap pelaksana membatur. Ada upacara membatur ini dilaksanakan satu hari setelah dikubur, ada yang 1 bulan, 
ada yang satu tahun bahkan ada yang sampai berpuluh tahun setelah meninggal baru dilaksanakan upacara membatur ini.

Ahli waris akan merancang pelaksanaan upacara membatur setelah salah seorang anggota keluarga atau tetua keluarga itu mendapat mimpi didatangi oleh arwah yang telah meninggal. Dalam mimpi tersebut arwah mengatakan bahwa mereka tidak mempunyai rumah di alam sana dan untuk itu dia meminta kepada keluarga yang masih hidup untuk dibuatkan sebuah rumah.

Pelaksanaan upacara membatur sebut dapat dilakukan kapan saja sesuai dengan kemampuan dari ahli waris. Bagi orang atau keluarga yang tidak mampu/tidak punya biaya untuk melaksanakan upacara membatur ini, tidak harus dilaksanakan pada tahun itu juga walau mereka telah mendapatkan mimpi itu. Ahli waris harus menabung terlebih dahulu karena untuk upacara membatur ini membutuhkan biaya yang besar karena biasanya akan memotong kerbau untuk persembahan.

Bagi keluarga yang tidak mampu, jika ingin melaksanakan juga upacara membatur ini, mereka tidak harus dilakukan di rumah sendiri tapi bisa juga menumpang atau ikut serta dengan keluarga yang lain dalam satu kelompok. Keluarga yang menumpang ini harus memberikan uang untuk membeli kerbau walau hanya sumbangannya sedikit. Selain untuk membeli kerbau mereka juga harus menyumbang untuk membuat batur atau rumah-rumahan yang terbuat dari kayu ulin.

Ada perbedaan dalam pelaksanaan membatur yang langsung dilaksanakan setelah meninggal dengan pelaksanaan membatur setelah beberapa lama meninggal. Apabila melaksanaan membatur dilaksanakan pada saat baru meninggal maka pengorbanannya tidak harus memakai kerbau tapi cukup dengan hewan kambing saja dan tidak tertutup kemungkinan mengorbankan kerbau bagi keluarga yang mampu.

\section{a. Tahap Persiapan}

Sebelum dilaksanakannya upacara membatur ini, terlebih dahulu diadakan rapat dalam keluarga besar/kelompok mereka. Dalam rapat ini dibicarakan tentang keluarga-keluarga yang akan melaksanakan upacara membatur (mendata jumlah orang yang meninggal dan akan di batur) serta penetapan hari pelaksanaan upacara membatur ini. Rapat persiapan ini menurut Setiawan (2009) diawali dengan rapat keluarga (kumpulan warga), dimana dalam rapat tersebut akan terkumpul banyaknya orang yang akan di batur dalam kelompok tersebut. Dalam rapat ini membicarakan niat untuk melaksanakan membatur, jumlah biaya serta kesanggupan tiap keluarga dalam mengeluarkan biaya yang diperlukan untuk penyelenggaraan upacara.

Keluarga yang tidak mampu sendiri dalam melaksanakan upacara membatur ini, akan bergabung dalam kelompok untuk menghemat biaya. Biasanya membatur dilaksanakan secara gabungan antara beberapa orang atau beberapa keluarga terutama yang masih dalam satu garis keturunan. Dengan demikian jumlah biaya serta persiapan perlengkapannya bisa dipikul secara bersama-sama. Pelaksanaan upacara membatur biasanya dipusatkan di salah satu rumah anggota keluarga yang telah disepakati. Tanggal pelaksanaan upacara juga dibicarakan dalam rapat keluarga tersebut 
Setelah itu dilaksanakan rapat tumpuk; yaitu rapat yang dihadiri oleh warga satu kampung atau keluarga-keluarga damang, penghulu adat, kepala desa dan tetuha kampung. Dalam rapat tumpuk ini membicarakan hari dan tanggal pelaksanaan upacara. Dalam rapat tumpuk ini juga ditentukan orang-orang yang akan membangun gagulang (dapur yang terletak di samping rumah), ambin (teras tambahan) dan petugas pengumpul kayu bakar. Setelah di dapat waktu yang tepat untuk melaksanakannya maka mulailah dilakukan persiapan-persiapan untuk pelaksanaan upacara ini.

Seminggu sebelum dilaksanakan membatur diadakan lagi pertemuan dalam kelompok tersebut. Rapat tersebut dinamakan dengan kumpulan jadi; yaitu rapat yang memutuskan pasti jadinya pelaksanaan membatur. Sebelum rapat ini dilaksanakan, dirumah tempat upacara dilaksanakan sudah di bangun gagulang dan ambin serta undangan untuk tamu telah di sebar. Dalam rapat kumpulan jadi sudah diputuskan siapa yang bertugas mengantar sesaji kekubur dan orang yang membuat batur.

Tahap persiapan pelaksanaan upacara dimulai dengan mencari bahan-bahan untuk membuat balai tempat pelaksanaan membatur ini seperti bambu, kayu dan rotan. Setelah bahanbahan yang dipakai untuk membuat balai tersedia, lalu dilanjutkan dengan pembuatan balai yang dikerjakan secara bergotong royong oleh semua penduduk laki-laki di desa tersebut. Balai tersebut menggunakan tiang kayu atau bambu, lantainya terbuat dari bambu atau papan dan bubungan atap terbuat dari kayu sungkai atau kayu lurus untuk tiang dan daun rumbia atau daun aren untuk atapnya.

Lokasi pendirian balai ini tergantung dari tempat pelaksanaan upacara membatur. Apabila upacara dilakukan ditempat keluarga atau menumpang untuk ikut upacara maka akan dipergunakanlah balai adat atau di rumah ketua kelompok. Sebaliknya apabila upacara membatur ini dilaksanakan sendiri maka balai tersebut di buat di depan rumah yang akan melaksanakannya. Selain mendirikan balai, masyarakat juga bergotong royong membuat batur beserta hiasanhiasan atau ukiran-ukirannya. Ukiran-ukiran yang di buat pada nisan biasanya bersifat umum seperti nenas, daun nenas dimana ukiran untuk laki-laki pada ujung atas ukiran tersebut di buat bundar dan ukiran untuk perempuan agak persegi empat dengan bentuk agak lancip sedikit (tergantung permintaan dari si mati).

Selain ukiran tersebut ada juga ukiran lain seperti manusia memegang tongkat yang melambangkan orang yang meninggal tersebut adalah pemuka masyarakat, ada juga ukiran orang pakai gelang dan ikat kepala yang melambangkan orang tersebut adalah seorang balian. Ukiran-ukiran tersebut dibuat oleh kepala kerja atau kepala tukang yang bisa membuat ukiran dan dibantu oleh kawan-kawan atau masyarakat lain untuk menyelesaikannya.

Persiapan ini juga termasuk dalam mengukir 4 sudut rerumahan yang akan di pasang di kuburan. Waktu pembuatan balai dan ukiran-ukiran tersebut adalah selama 1 (satu) minggu. Pembuatan batur dan balai tersebut selesai satu hari sebelum dilaksanakannya upacara membatur ini. 
Alat dan bahan yang di pakai dalam pelaksanaan upacara membatur ini adalah (1) Tombak, digunakan untuk menombak kerbau persembahan, (2) buluh, sejenis tumbuhan bambu yang di pakai untuk melemang dan memasak sesajen ini (3) ayam, biasanya di pakai untuk sesajen dan sebagai variasi menu masakan.

Untuk sesajen diambil dari tubuh hewan persembahan (kerbau) yaitu buah zakar, usus, daging tulang belakang, sendi tulang, kulit bagian kepala (sangkeat, kepala kerbau dikuliti dan dalam prosesnya kulit tersebut tidak boleh putus), hati, jantung, paru-paru, lidah/ilat, segala isi perut. Sementara untuk sesajen selain dari tubuh hewan persembahan antara lain biji sahang/ merica, pisang talas/tuhu, Kalau pisang talas tidak ada dapat diganti dengan pisang Palembang yang berukuran agak kecil-kecil atau bisa juga dengan pisang muda, garam, jagung, umbut enau, umbut pinang, dan umbut kelapa.

Semua bahan-bahan dari tubuh hewan dipotong kecil-kecil dan kemudian dimasukkan ke dalam buluh. Selain di isi dengan potongan dari tubuh hewan, buluh tempat sesajen tadi juga di isi dengan cincangan dari tumbuh-tumbuhan dan buah-buahan. Setelah bahan-bahan sesajen tersebut disatukan dalam buluh lalu buluh-buluh tadi dimasukkan ke dalam kirai (anyaman dari rotan).

Setelah itu buluh-buluh tersebut di masak dengan cara di bakar/di lemang. Jumlah buluhbuluh untuk sesajen tergantung dari siapa yang di batur. Ketika yang di batur adalah laki-laki maka jumlah buluh yang harus dipersiapkan berjumlah 14 potong buluh. Sedangkan apabila yang di batur adalah perempuan maka jumlah buluh yang dipersiapkan adalah 7 potong buluh ${ }^{4}$. Pada masyarakat Dayak Balangan, ada beberapa pantangan dalam pelaksaanan ritual, diantaranya Wanita yang sedang haid tidak boleh untuk memasak/mengukus makanan yang akan dijadikan sesajen (selain untuk sesajen boleh dikerjakannya). Tidak boleh ada daging babi dalam sesajen ataupun dalam jamuan makan karena sifat upacara yang berhubungan langsung dengan Tuhan sehingga semua makanan itu harus suci5.

\section{b. Jalannya Upacara}

Pada hari yang telah disepakati untuk melaksanakan upacara maka dimulailah segala ritual untuk memulainya yang dipimpin oleh balian/tabib. Balian ini merupakan orang yang berfungsi sebagai penghubung dengan roh-roh halus dan di bantu oleh pasambe atau patati.

\footnotetext{
${ }^{4}$ Apabila yang akan dibatur tersebut berada (dikubur) di luar kampung, maka dapat diambil tulang belulangnya dan dibawa ke kampung, untuk selanjutnya dikubur ulang di kampung tersebut. Seminggu sesudahnya diadakan upacara selamatan di rumah yang membatur tadi. Lauk yang dimasak biasanya adalah ayam. Selamatan wajib menyediak ayam minimal 1 ekor untuk sesajen sedangkan lauk pauk lainnya terserah pada tuan rumah.

${ }^{5}$ Dalam keseharian, masyarakat dayak mengkonsumsi daging babi. Namun dalam melaksanakan ritualnya mereka tidak memakai hewan babi sebagai binatang persembahan. Mereka beralasan, kalau yang dipersembahkan itu harus binatang yang cepat di terima oleh Tuhan, dan babi mereka anggap sangat lambat penerimaannya oleh Tuhan. Hal ini dipengaruhi oleh beragamnya agama yang pernah mereka anut. Masyarakat Dayak Halong sebelum pemeluk agama Budha, mereka juga pernah memeluk agama Kristen, Khatolik, Hindu dan Islam. Selain itu tujuan dari pelaksanaan ini adalah keinginan untuk berbagi, dimana mereka akan membagikan daging hewan persembahan ke warga sekitar tanpa mengenal agama dan etnis.
} 
Pasambe atau patati ini adalah orang (wanita) yang membantu balian menyusun sesaji dan juga menguasai jenis sesaji yang diperlukan oleh balian.

Apabila upacara membatur ini menggunakan kerbau sebagai hewan persembahan, maka diadakanlah acara menombak kerbau. Untuk membunuh kerbau persembahan tersebut haruslah terlebih dahulu di tombak sebelum kerbau tersebut di sembelih, sedangkan bila memakai hewan kambing sebagai hewan persembahan hanya di potong atau di sembelih. Hewan yang akan dipotong tergantung dari siapa yang meninggal, bila laki-laki maka yang dipotong adalah kerbau jantan, begitu juga sebaliknya. Apabila yang di batur jenis kelaminnya sama, maka hewan persembahannya bisa satu saja, namun apabila yang di batur berbeda jenis kelaminnya maka hewan persembahannya pun harus berbeda jenis kelaminnya.

Sebelum dilaksanakannya acara menombak kerbau, terlebih dahulu dilakukan pembacaan doa atau mantera oleh tokoh tabib atau balian yang membacakan doa-doa untuk memanggil arwah-arwah dari keluarga mereka yang telah mati beserta arwah-arwah yang lainnya. Pembacaan doa ini dilaksanakan di balai (di kepala tangga) tempat pelaksanaan upacara tersebut dilakukan. Dalam prosesi ini tabib atau balian membaca mantera-mantera yang antara lain adalah melapokan pada arwah-arwah leluhur keluarga dan yang punya kaitan keluarga, dan siapa yang kena waris. Sambil membaca mantera, balian atau tabib tersebut akan membunuh ayam sebagai media penyampaian doa dengan cara memukul leher ayam tersebut (tidak di bunuh dengan cara disembelih).

Setelah ayam tersebut mati, lalu di cabut bulu-bulunya. Semua proses ini dilakukan oleh pembantu (patati) dari balian tadi. Ayam yang telah di mantrai itu kemudian di masak untuk bisa di makan dalam jamuan makan siang atau setelah pemotongan kerbau. Pembacaan doa ini biasanya dilaksanakan oleh 2-5 orang balian. Selesai pembacaan doa barulah dilaksanakan pemotongan kerbau. Pemotongan kerbau persembahan tersebut dilaksanakan di lapangan terbuka. Sebelum dilaksanakan pemotongan kerbau, dilapangan tempat pemotongan tersebut juga dilakukan ritual-ritual atau membaca doa yang dibacakan oleh tabib dan penombakan dilakukan oleh perwakilan dari pihak puhun atau penyelenggara membaca bacaan-bacaan ${ }^{6}$ tertentu sambil memakan jarianggau ${ }^{7}$. Orang yang ditunjuk dalam melaksanakan kegiatan disebut dengan kesarahan ${ }^{8}$.

\footnotetext{
${ }^{6}$ Bacaan tersebut berupa mantera-mantera yang meminta izin kepada roh-roh supaya pada saat melakukan tugas mereka tidak pangadiawan atau lupa apa yang kan mereka kerjakan. Dari wawancara dengan salah satu balian, lupa kaingatan ini diakibatkan gangguan roh-roh leluhur dimana mereka marah karena penyelenggara tidak meminta izin untuk melaksanakan kegiatan tersebut.

${ }^{7}$ memakan jarianggau merupakan sebuah kewajiban bagi setiap orang sebelum memanggil arwah.

Menurut kepercayaan setempat, kalau tidak memakan jarianggau orang-orang tidak boleh memanggil arwah karena jarianggau merupakan media yang paling penting.

${ }^{8}$ Orang-orang yang ditunjuk ini adalah hasil musyawarah pihak puhun dengan pihak waris. Waris dalam masyarakat dayak Halong adalah sepupu satu kali dari pihak puhun. Orang yang ditunjuk boleh menolak dengan alasan tidak biasa melakukan pekerjaan tersebut atau memiliki hubungan kerabatan dengan pihak puhun. Biasanya orang yang diserahkan tugas tersebut dimulai dari sepupu dua kali dan seterusnya. Semakin jauh hubungan kekerabatan maka semakin besar peluang dia menjalnkan tugas tersebut.
} 
Kerbau yang akan di tombak tersebut terlebih dahulu di ikat di pohon nyiur/kelapa atau pohon-pohon lain yang kuat dan mampu menahan pergerakan dari kerbau tersebut. Pada proses selanjutnya pada bagian pinggang kerbau tersebut ditandai dengan bulatan dan garis putih yang melingkar di seputaran leher tersebut. Ada aturan dalam penombakan kerbau yang dilaksanakan dalam masyarakat Dayak Halong. Dalam menombak kerbau tersebut harus ditujukan pada bagian-bagian kerbau tersebut dari kepala sampai dada yang dibatasi oleh garis putih yang melingkar ${ }^{9}$. Apabila penombakan dilakukan di luar garis tersebut akan dikenakan denda yang akan diputuskan dalam rapat adat. selain itu orang yang menombak kerbau dan tombaknya lepas maka ia juga akan dikenakan denda. Jumlah denda yang akan dikenakan pada si penombak adalah sebesar 2 real. $^{10}$

Proses penombakan kerbau ini dilakukan oleh 7-14 orang yang terdiri dari perwakilan dari desa yang diundang yang ada kepengurusan adatnya.. Apabila yang di batur adalah perempuan, jumlah orang yang menombak kerbau tersebut berjumlah 7 orang. Sedangkan apabila yang di batur adalah laki-laki, maka jumlah orang yang menombaknya berjumlah 14 orang. Sebelum penombakan, para tokoh yang akan menombak akan membaca doa sebelum memulai tugas mereka. Dalam doa tersebut diceritakan bahwa waktunya (para arwah) telah sampai di sini dan dia yang akan di tombak ini akan ke tempat mereka (alam arwah). Dalam doa tersebut juga disebutkan bahwa kerbau yang di tombak itu tidak sekedar hewan persembahan tapi merupakan kendaraan bagi para arwah untuk mempercepat mereka ke tempat mereka yang sesungguhnya.

Penombakan kerbau tersebut tidak sampai hewan itu mati, dimana tetapi setelah itu di sembelih atau di potong oleh orang yang telah di tunjuk. Orang yang di tunjuk ini biasanya orang yang telah biasa dalam menyembelih hewan dan yang penting harus seorang muslim. Hal ini dimaksudkan agar daging hewan kerbau ini bisa dinikmati oleh masyarakat di sekitar kampung. Setelah di sembelih, lalu dagingnya dipotong-potong dan dipisahkan mana yang untuk dijadikan sesajen dan mana daging sebagai menu untuk makan pada sore harinya. Setelah selesai dipotong-potong dan dipisahkan lalu daging yang untuk di makan tersebut dimasak secara gotong royong oleh para lelaki di halaman rumah tempat pelaksanaan upacara. Daging tadi di masak dalam wajan besar (digangan) dengan cara di gulai. Selain daging kerbau, untuk menambah variasi makanan juga ada daging ayam, daging kambing (bagi yang mampu) dan sayur-sayuran.

Bagian tubuh dari kerbau yang dianggap penting diambil untuk dijadikan sebagai sesajen, seperti usus, daging tulang belakang, sendi tulang, kulit bagian kepala (sangkeat) dimana dalam pengambilannya tidak boleh putus. Selain itu juga di ambil hati, jantung, paru-paru, lidah/ilat/ bela dan isi perut. Bagian kerbau yang diambil tersebut lalu dipotong-potong kecil (dicincang)

\footnotetext{
${ }^{9}$ Maksud di beri pembatas supaya tidak kena lambung, dimana kotoran terdapat di situ, sehingga kotoran tidak mengotori daging yang lainnya.

${ }^{10}$ Harga 1 real bagi masyarakat dayak halong adalah sebesar Rp.2000. Menurut salah seorang informan, saat ini sedang di susun sebuah keputusan adat untuk menaikkan harga 1 real tersebut menjadi Rp. 10.000. Hal ini dilakukan karena denda sebesar itu sudah dianggap tidak layak lagi dan bagi pelanggarnya denda sebesar ini ibarat sebuah lelucon.
} 
lalu dimasukkan ke dalam buluh. Selain daging atau bagian dari kerbau tadi juga dimasukkan biji sahang/merica, pisang talas/tuhu, ${ }^{11}$ garam, jagung, pucuk pohon enau dan pucuk pohon kelapa. Kemudian buluh-buluh tadi di masak dengan cara di bakar seperti lemang. Setelah masak lalu buluh-buluh tadi dimasukkan ke dalam kirai ${ }^{12}$.

Jumlah buluh yang di susun dalam kirai ini tergantung jenis kelamin yang di batur. Apabila yang dibatur berjenis kelamin laki-laki, maka jumlah buluh yang disediakan berjumlah 14 potong. Sedangkan jika yang dibatur adalah perempuan maka jumlah buluh yang disediakan berjumlah 7 potong buluh.

Pada saat prosesi memasak daging hewan persembahan tadi, orang tua atau balian yang membaca mantera pada saat proses awal kemudian pergi ke kuburan. untuk memasang peti batur yang terbuat dari kayu ulin. ${ }^{13}$ Selain itu balian juga membawa bumbung solok yang telah di masak tadi. Selain memasang peti batur, balian dan puhun juga membaca doa dan bumbung solok $^{14}$ kemudian diletakkan di atas pusara yang gunanya sebagai persembahan ke alam arwah. Bumbung solok ini berisi segala macam potongan daging dan rempah-rempah lainnya untuk sesajen. Setelah pembacaan doa di makam selesai, tabib/balian lalu pulang ke rumah untuk mandi menyucikan badan. Pada malamnya diadakan makan bersama dengan pihak puhun dan undangan dengan lauknya adalah kerbau yang telah di sembelih siangnya.

Setelah semua acara selesai yang diakhiri dengan makan bersama, yang dilanjutkan dengan acara undang adat, yaitu acara yang khusus membicarakan masalah warisan dari yang telah meninggal, baik itu berupa hutang, harta benda atau hal lainnya. Undang adat ini akan sangat berguna apabila ahli waris dari yang telah meninggal ini berperkara masalah harta benda dan warisan yang ditinggalkan. Semua permasalahan tersebut akan diselesaikan dalam acara ini.

Selesai acara undang adat, lalu diadakan acara adat berpalas. Acara ini dilakukan sore hari sesudah semua rangkaian upacara selesai (keesokan harinya). Acara berpalas ini ditujukan pada semua orang yang telah bekerja membantu pelaksanaan acara membatur ini. Jika acara berpalas ini tidak dilaksanakan, maka luka yang terdapat pada tubuh seseorang ketika bekerja (misalnya kena api, kena catok/luka kena pisau, dll) akan sulit sembuh. Untuk membersihkan semua luka itu menggunakan darah ayam, darah kerbau dan beras. Semua bahan ini disatukan dalam sebuah tempat, kemudian campuran ramuan tadi dioleskan ke kaki, tangan dan bagian tubuh lainnya.

\footnotetext{
${ }^{11}$ Kalau pisang talas tidak ada dapat juga di ganti dengan pisang Palembang yang berukuran agak kecil-kecil. Pisang yang dijadikan sesaji ini tidak harus pisang yang sudah masak tetapi dapat juga diganti dengan pisang yang masih muda,

${ }^{12}$ Anyaman yang berbentuk seperti bakul yang pada bagian atasnya dikasih bingkai (ini yang membedakan dengan bakul, bakul tidak pakai bingkai di bagian atasnya. Kirai ini terbuat dari hati rotan (apak). Kirai ini memiliki diameter dan tinggi yang sama yaitu sekitar $30 \mathrm{~cm}$.

${ }^{13}$ Peti batur tersebut pada saat sekarang boleh diganti dengan semen karena sudah mulai jarangnya kayu ulin di Kabupaten Balangan. Akan tetapi nisannya tidak boleh diganti, tetap harus terbuat dari kayu ulin

${ }^{14}$ Bumbung solok merupakan tempat sesajen yang berupa bambu dengan ukuran kecil kurang lebih berdiameter $5 \mathrm{~cm}$ dengan tingginya sekitar $20 \mathrm{~cm}$.
} 
Ada pantangan yang harus dipatuhi oleh masyarakat selama membatur ini. Pantangan tersebut antara lain tidak boleh kawin/pesta, berkebun, menyadap karet dan menggarap ladang selama 1 hari setelah selesainya acara membatur ini. Pantangan ini dilakukan karena dikhawatirkan orang-orang yang bekerja tersebut akan diikuti oleh roh yang dibatur sehingga dapat menyebabkan panas/demam.

\section{c. Upacara dan Pembentukan Karakter}

Seperti yang telah diuraikan di atas, setiap tahapan pelaksanaan upacara membatur ini penuh dengan pendidikan karakter bagi masyarakat pendukungnya. Dalam upacara membatur ini dapat kita lihat beberapa pendidikan karakter dalam pelaksanaan upacara ini. Pendidikan tersebut antara lain :

\section{Musyawarah mufakat}

Musyawarah dan mufakat di mulai sejak tahap perencanaan sampai pada tahap pelaksanaannya. Pada tahap perencanaan, semua orang yang ikut sebagai pelaksana dalam upacara ini mulai bermusyawarah untuk membicarakan niat untuk melaksanakan upacara membatur, jumlah biaya yang akan dikeluarkan, serta kesanggupan tiap keluarga dalam mengeluarkan biaya yang diperlukan untuk penyelenggaraan upacara.

Keluarga yang tidak mampu melaksanakan upacara membatur ini sendirian (keluarga itu sebagai penanggung dana), akan bergabung dalam kelompoknya untuk menghemat biaya. Dalam pelaksanaan upacara ini biasanya dilaksanakan secara gabungan atau berkelompok beberapa keluarga terutama yang masih dalam satu garis keturunan. Dengan demikian jumlah biaya serta persiapan perlengkapannya bisa dipikul secara bersama-sama.

Pelaksanaan upacara membatur biasanya dipusatkan di salah satu rumah anggota keluarga yang telah disepakati. Tanggal pelaksanaan upacara juga dibicarakan dalam rapat keluarga tersebut.

Setelah rapat pertama dalam kelompok tersebut selesai dan di dapat keputusan, dilanjutkan dengan rapat tumpuk; yaitu rapat yang dihadiri oleh warga satu kampung atau keluarga-keluarga damang, penghulu adat, kepala desa dan tetuha kampung. Dalam rapat tumpuk ini membicarakan hari dan tanggal pelaksanaan upacara. Dalam rapat tumpuk ini juga ditentukan orang-orang yang akan membangun gagulang (dapur yang terletak di samping rumah), ambin (teras tambahan) dan petugas pengumpul kayu bakar. Setelah di dapat waktu yang tepat untuk melaksanakannya maka mulailah dilakukan persiapan-persiapan untuk pelaksanaan upacara ini.

\section{Kerjasama atau gotong royong}

Kerja sama ini dalam pelaksanaan upacara ini dapat terlihat dari hasil rapat tumpak untuk pelaksanaan upacara ini. Dalam rapat tersebut dapat terlihat yang bekerja itu bukan hanya pihak pelaksana, tetapi juga pekerjaan seluruh warga di kampung itu. Mencari kayu bakar dan perlengkapan lain untuk upacara, membangun gegulang dan 
ambin biasanya dikerjakan oleh laki-laki. Sementara untuk wanita nya memasak dan membuat sajen dalam pelaksanaannya nanti.

Dalam memasak pun ada pembagiannya. Laki-laki biasanya akan memasak untuk pekerjaan yang berhubungan dengan api yang besar seperti memasak nasi dalam jumlah yang besar dan memasak gulai.

\section{Jujur}

Jujur menurut Kamus Besar Bahasa Indonesia adalah lurus hati; tidak berbohong; tidak curang (misalnya dalam permainan, dengan mengikuti aturan yang berlaku): tulus; ikhlas. Dalam upacara adat membatur ini jujur yang dikasud adalah jujur tentang keadaan diri sendiri, terutama untuk wanita yang membuat sesajen. Wanita yang membuat sesajen haruslah dalam keadaan bersih, suci atau tidak dalam keadaan kotor. Seorang wanita yang lagi kotor atau tidak bersih (haid, menstruasi) tidak boleh membuat makanan yang diperuntukkan buat sesajen. Menurut informan, hal ini sangat diperhatikan karena sajen yang di buat tersebut diperuntukkan pada roh-roh tetua dan dewa-dewa dan itu harus dalam keadaan bersih juga. Selain itu daging babi tidak dipakai dalam setiap upacara yang dilakukan. Tidak ada seorangpun yang mau berbuat curang tentang keadaan diri mereka agar bisa membuat sesajen karena akan dapat mendatangkan musibah bagi orang kampung.

\section{Patuh}

Patuh menurut Kamus Besar Bahasa Indonesia adalah suka menurut (perintah dan sebagainya); taat (pada perintah, aturan, dan sebagainya); berdisiplin. Kaitan dengan upacara ini adalah patuhnya masyarakat dalam menjalankan semua larangan yang ada setelah selesainya upacara. Masyarakat Dayak Balangan, mematuhi beberapa pantangan dalam pelaksaanan ritual. Seperti wanita yang sedang haid mempunyai pantangan tidak boleh untuk memasak/mengukus makanan yang akan dijadikan sesajen (selain untuk sesajen boleh mengerjakannya). Tidak boleh ada daging babi dalam sesajen ataupun dalam jamuan makan juga merupakan pantangan karena sifat upacara yang vertikal sehingga semua makanan itu harus suci.

Pantangan lain yang harus dipatuhi oleh masyarakat selama membatur ini adalah tidak boleh kawin/pesta, berkebun, menyadap karet dan menggarap ladang selama 1 hari setelah selesainya acara membatur ini. Pantangan ini dilakukan karena dikhawatirkan orang-orang yang bekerja tersebut akan diikuti oleh roh yang dibatur sehingga dapat menyebabkan panas/demam. Dan selama ini larangan tersebut dipatuhi oleh semua lapisan masyarakat di Dayak Halong.

\section{PENUTUP}

Pelaksanaan upacara tradisional, khususnya upacara membatur ini bagi masyarakat Halong tidak hanya sekedar ritual, tetapi banyak nilai-nilai sosial yang dapat membentuk karakter masyarakat di dalamnya. Menentukan waktu pelaksanaan upacara harus melalui musyawarah mufakat, membina kerja sama dan gotong royong serta nilai- nilai lainnya merupakan bagian 
yang tidak terpisahkan dari pelaksanaan upacara tersebut. Begitu banyaknya nilai-nilai positif yang terkandung dalam pelaksanaan upacara tersebut, maka seharusnya masyarakat dapat menjaga keberlangsungan upacara tersebut.

\section{DAFTAR PUSTAKA}

Adibatin, Ani. 2016. Pendidikan Karakter Bangsa Berbasis Strategi Pembelajaran Pakem Melalui Permainan Cincin Di Jempol Tangan (Karya Inovasi Pembelajaran Sekolah Dasar). dalam Jurnal Pendidikan dan Kebudayaan. Vol. 6 No. 1 Salatiga

Ajisman, dkk. 1998. Perubahan Upacara Tradisional Pada Masyarakat Pendukungnya. Proyek Pengkajian dan pembinaan nilai-nilai budaya Propinsi Kalimantan Barat

Guntara, Fuad. dkk. 2016. Kajian Sosial Budaya Rambu Solo’ Dalam Pembentukan Karakter Peserta Didik. Dalam Jurnal Pendidikan: Teori. Penelitian dan Pengembangan. Vol. 1 No. 2. Februari. Universitas Negeri Malang

Jenks, Chris. 2013. Culture, Studi Kebudayaan. Yogyakarta : Pustaka Pelajar.

Liliweri, Alo. 2014. Pengantar Studi Kebudayaan. Bandung : Nusa Media.

Maryadi, Sisva. 2010. Upacara Adat: Sebuah Daya Tarik Wisata Budaya (Studi Upacara Adat Dayak Halong Kabupaten Balangan Kalimantan Selatan). Pontianak : Balai Pelestarian Sejarah Dan Nilai Tradisional Pontianak.

Maryadi, Sisva dkk. 2014, Pengobatan Tradisional Masyarakat Dayak Halong di Kabupaten Balangan Kalimantan Selatan. Pontianak : Balai Pelestarian Nilai Budaya

Nugraha, 2012. Pentingnya Pembelajaran Kontekstual Untuk Membentuk Karakter Siswa. Citizenship, Jurnal Pancasila dan Kewarganegaraan. Vol. 1 No. 1. Universitas PGRI. Madiun

Setyawan, Dharma. 2009. Upacara Membatur, Upacara Kematian pada Masyarakat Dayak, dalam Buletin Bandarmasih. Edisi No. 25 Volume I Tahun 2009, Museum Lambung Mangkurat. Banjarmasin

Syamsudin, Helius. 2001. Pegustian dan Tumenggung: Akar Sosial, Politik, Etnis dan Dinasti, Perlawanan di Kalimantan Selatan dan Kalimantan Tengah 1859-1906. Jakarta : Balai Pustaka.

Wardani. Naniek Sulistya. 2015. Pengembangan Nilai-Nilai Budaya Sekolah Berkarakter. Jurnal Scholaria, Jurnal Pendidikan dan Kebudayaan. Vol. 5. No. 3. Satya Wacana University Press, Salatiga

Yusuf, Wiwik P. Dkk, 1982/1983. Upacara Tradisional (Upacara Kematian) Daerah Sulsel. Proyek Inventarisasi dan Dokumentasi Kebudayaan Daerah. Jakarta : Depdikbud.

\section{SUMBER INTERNET}

http://kbbi.go.id

http://kbbi.web.id/karakter. di unduh tanggal 30 agustus 2016 